\title{
Education for Critical Community and the Pedagogy of Asylum: Two Responses to the Crisis Of University Education
}

\author{
Leszek Koczanowicz' (iD $\cdot$ Rafał Włodarczyk ${ }^{2}$ (D)
}

Accepted: 4 August 2021 / Published online: 31 August 2021

(C) The Author(s) 2021

\begin{abstract}
The current heated debate on the deteriorating status of the university raises a range of pertinent questions, including: What role can the humanities play in culture today in the face of the crisis of higher education? To answer this question, the authors begin by problematizing the relationship between culture, the humanities, and education. In the second part of the paper, they examine the changing role of the humanities in conjunction with the understandings of culture, and outline three salient ways in which culture is conceived of today. Subsequently, they focus on the loss of the dominant status that culture suffered when everyday life was discovered in modernity. In the third part, they argue that everyday life, or rather social representations of everyday life and its practices, are currently becoming the chief criterion for assessing culture, the humanities, and education. However, everyday life remains complex both in theoretical conceptualizations and in research observations. For example, everyday life harbors a range of risks and anxieties which are veiled by its own obviousness and reinforced by socialization. The authors conclude that, given this, everyday life in democratic societies calls for the work of understanding, support, affirmation, and criticism, in which the humanities can retain their superior status. In the fourth part, the authors discuss non-consensual democracy, critical community, and the pedagogy of asylum as the forms of organization and action that promote an auspicious interconnection of culture, the humanities, and education.
\end{abstract}

Keywords Humanities · Education · Everyday life · Non-consensual democracy · Critical community $\cdot$ Pedagogy of asylum

Leszek Koczanowicz

1koczanowicz@swps.edu.pl

Rafał Włodarczyk

rafal.wlodarczyk@uwr.edu.pl

1 Department of Cultural Studies, SWPS University of Social Sciences and Humanities Poland, Warsaw, Poland

2 Faculty of Historical and Pedagogical Sciences, University of Wrocław, Wroclaw, Lower Silesia, Poland 


\section{Introduction: Culture, the Humanities, and Education}

In recent years, there has been an upsurge of studies on the crisis of university education. Concomitantly, the Western university has ceased to be perceived as a relatively autonomous agora of autotelic expert knowledge, and has come to be treated as one of the many social institutions which are expected to deliver services and products catering to current needs and to be subservient to the public and commercial agendas. From this perspective, higher education and university research are understood as investments in knowledge which help further the socio-economic development of states, solve global problems, and facilitate people's everyday lives.

This cursory outline does not do justice to the comprehensive literature on the issue, and only gestures at the two extreme stances in current debates on higher education and on the role of the humanities in university education. Of course, there is an array of intermediate positions between the two poles of the university as a respected and autonomous depositary of autotelic knowledge, on the one hand, and the university as a producer of socially and economically useful, practicable solutions and technologies, on the other. To be meaningfully explored, the role of the humanities in academic education must be located in a broader context of the overall role of the humanities in culture, which is reflected in education, including university studies. The question is what role the humanities can play in culture today in the face of the crisis of higher education. Importantly, in the context of enculturtion and the current complexities of social life, higher education is but one among impactful socializing institutions (school, family, media, religious organizations, etc.), which may differ not only in how they exert their cultural influence, but also in what values they disseminate. Moreover, academic education in Western societies has traditionally trained the personnel and the elites to perform their assigned social roles, and inculcated upper-strata knowledge, practices, and ways of life in students. Consequently, no sound inquiry into the role of the humanities in culture and in higher education may ignore particular social conditions.

To go back to our question about the role of the humanities in today's culture marked by the crisis of university education, the humanities have for centuries been the vehicle and the pillar of culture, as well as a means of instilling cultural values in students. This tradition dates back to Cicero and his concept of cultura animi. In the Tusculan Disputations, Cicero spells out the responsibility of humanistic education: "Whereas philosophy is the culture of mind: this it is which plucks up vices by the roots; prepares the mind for the receiving of seeds; commits them to it, or, as I may say, sows them, in the hope that, when come to maturity, they may produce a plentiful harvest" (Cicero 2005: II.5). For the Stoics, this cultivation culminated in erecting an "inner citadel," as phrased by Marcus Aurelius (Hadot 2001). Far from being an indifferent theoretical exercise, philosophy is a way of life that enables us to survive misery and brave adversities, which fate abundantly visits on us (Pascal 1984). By common consensus, Cicero's usage of cultura references farming, and philosophy-a conceivable equivalent of the humanities in Cicero's times - is the main tool for cultivating the mind. Later, as the modern concept of the university was being forged, the humanities were more comprehensively understood as encompassing other fields, such as history, classical philology, the study of modern languages and literatures, etc. Nevertheless, philosophy retained its status as the central discipline, in the sense of providing education with a general theoretical perspective. 
Humanistic education has been appointed a similar role in other cultures as well. For example, in antiquity (and later on), Chinese literati were given classical literary education to prepare them, in the Confucian spirit, for performing various functions in the bureaucratic administration and the social life of the empire. The study of philosophy was expected to trigger an inner transformation in scholars, and thus to help them abide by a certain tradition-molded ethos in life and in profession. Zengzi, one of Master Kong's disciples, confesses in the canonical Analects of Confucius: "Every day I examine myself on three counts: in my dealings with others, have I in any way failed to be dutiful? In my interactions with friends and associates, have I in any way failed to be trustworthy? Finally, have I in any way failed to repeatedly put into practice what I teach?" (2003: I.4). The study of philosophy and literature is envisioned as the mainstay and a means of inseminating the minds of students with cultural values and as a way of life through which harmonious relations are sustained in a society of intelligible structure and recognizable statuses. This notion of the interconnectedness of the humanities, education, and culture corresponds to Cicero's cultivation of the soul. Notably, even though the concept of cultura animi has gone through a series of changes since antiquity, the word "culture" still connotes the cultivation of the mind (Eagleton 2000: 7-34).

At the same time, as the humanities developed into a more inclusive field beyond philosophy alone, the relationship between the humanities and culture, in particular the part of culture that underpins intergenerational transmission, became far more complicated. While the humanities form the core of culture, they simultaneously depend on culture. This dual bond between the humanities and culture makes the humanities pivotal to education. The humanities are, as it were, responsible for how culture is conceptualized in education, particularly in the education system. To examine this bond in the context of the role that the humanities have in culture now, as university education is steeped in crisis, we must first establish how the role of the humanities mutates along with the changing understandings of culture itself. Consequently, the second part of this paper surveys three salient notions of culture which stand out as relevant to our goals amidst a multitude of contemporary representations of culture. This will be helpful in defining the "crisis of culture," which caused culture to lose its privileged position as a goal in and of itself, achievable through educational practices, essentially including higher education. The dynamic of Western modernity brought about the "crisis of culture" in which the autotelicity of culture was put into question as a result of and in parallel with the gradual discovery of everyday life. This development is examined in the third part of this paper. Consequently, we argue, a reversal has taken place in which everyday life or, more precisely, social representations of everyday life and its practices have come to serve as criteria for appraising culture, the humanities, and education. In other words, the value and centrality of everyday life are framed as indisputable. At the same time, everyday life is the common denominator of politics, education, and other social institutions in culturally diverse, multiethnic democratic societies. Any attempt to define the role that the humanities can play in culture today in the face of the crisis of higher education must take into account this fundamental transformation experienced in Western societies.

We address this issue within the theoretical framework of our concepts of non-consensual democracy, critical community, and the pedagogy of asylum, which are depicted in the fourth part of this paper. These concepts have furthered out understanding of the pivotal transformation prompted by the dynamics of modernity and helped us recognize the crisis of culture as generating some opportunities for the humanities, that is, approaches which make 
their role in culture and contemporary Western societies more intelligible. Our concepts are certainly neither the only method for working through the crisis of culture nor the only right perspective for the humanities and education. Nonetheless, the concepts of non-consensual democracy, critical community, and the pedagogy of asylum reinforce impulses flowing from the humanities and capitalize on and secure their potential, which is a sine qua non of our self-awareness.

The concept of non-consensual democracy pivots on Mikhail Bakhtin's vision of dialogue as reducing the distance between the parties involved in it (Koczanowicz 2015). If only dialogue takes place, it serves as a medium of understanding, and only exceptionally leads to comprehension or a more or less accepted agreement. The practice of dialogue as understanding alone is an important aspect in the operations of critical community. For such a community, intersubjective dialogue means a discussion with and an ongoing revision of the tradition/s of the interlocutors. Such a dialogue makes it possible to avoid ignoring multi-level contextual enmeshments of the interlocutors in cultural and environmental/communal resources, which determine their enculturation and socialization and in which they can achieve self-fulfillment. At the same time, such a dialogue helps communities avoid being sealed up around the belief that their traditions and the ways of making sense of their core values are immutable, a belief that impedes or precludes both self-understanding and understanding others. In brief, what is at stake in such a dialogue with tradition/s is critical assimilation rather than the rejection or acceptance of diverse traditions, especially of their controversial elements. Critical community has its corresponding political form in nonconsensual democracy, in which institutions seek to promote mutual understanding among various political groupings and social groups. Critical community and non-consensual democracy importantly foster continuity between everyday life and politics, which will be discussed more thoroughly below.

The pedagogy of asylum (Włodarczyk 2009) represents a form of education which may equip individuals and groups with competencies for pursuits dovetailing with the ideas of critical community and non-consensual democracy (Włodarczyk 2009). The construction of critical community and non-consensual democracy must commence somewhere, and neither education designed to nurture them nor education designed to promote their continuity and permanence must be at variance with them. To jump ahead of our argument, asylums resemble miniature critical communities, which operate in conformity with the idea of non-consensual democracy. The pedagogy of asylum builds on Emmanuel Levinas's interpretation of subjectivity as hospitality that welcomes another human being (Levinas 1969: 27), on his insistence on responsibility for the Other, and on his notion of ethics as first philosophy (Levinas 1998a: 1-11; Levinas 1991: 157-161). In line with Levinas's thought, living up to the ethics of hospitality is a challenge to everyday life dominated, as it is, by social and legal norms, cultural models, and customs that stand in stark contrast to Levinas's radically conceived responsibility for and to the Other. The point is that basic socializing institutions, such as family, school, media, religious organizations, associations, peer and friendly groups, workplaces, and governmental agencies, do not foster the habits of decision-making informed by subjective sensitivity, which is Levinas's ethical injunction (1991: 99-129). Given this, education for Levinasian hospitality calls for an asylum which operates in ways alternative to the dominant moral order and produces conditions of possibility for experiencing relations in compliance with the ethics of hospitality. Habits and experiences developed in asylums may be used by individuals as points of reference 
in other social spaces and in their everyday lives. In this way, the pedagogy of asylum creates proper conditions for learning to tolerate disagreement and conflict and, at the same time, for developing commitment to understand other people's motives and attitudes and to engage in dialogue with the cultural legacy of one's own community. Indispensable for critical community and non-consensual democracy, such a mindset is achievable through a gradual expansion of the ethics of hospitality beyond asylums.

By arranging our argument in these stages and discussing the concepts of non-consensual democracy, critical community, and the pedagogy of asylum, we will be able to answer our central question: What role can the humanities play in culture today in the face of the crisis of university education?

\section{Three Models of the Interrelatedness of Culture, the Humanities, and Education}

The role of the humanities hinges on the way that culture is understood. Hence, attempts to grasp the impact of the crisis of culture on the humanities and education must start from establishing how they are interrelated. There are three major contemporary concepts of culture that, we believe, correspond to important social representations of culture and provide a valid point of reference for educational practice in Western societies. In one of these concepts, culture is a repository of worldwide, though in fact mainly Occidental, progressive social ideals, models of perfection, and ways of accomplishing them. Another concept binds culture to the national identity proper to a given community which lives together on and dominates a separate territory of its own, or aspires to such a life and to such a territory. The third concept holds that religion and faith lie, interconnected, at the heart of culture, defining the destiny of man and the world, and obligating a given religious community to be guided by their doctrine in pursuit of its goals. Though interlaced in social practice, the three concepts will be examined separately for the sake of lucidity.

One of these three models assumes that culture brings us closer to the ideal of unity rooted in the cultivation of the mind. This may be the most classic concept since it explicitly builds on Cicero's notion of cultura animi. In the 19th century, this idea was preached by Matthew Arnold in his essays in Culture and Anarchy. Crucially, culture represents here not only the ideal of perfection, but also a social ideal: "It [culture] seeks to do away with classes; to make the best that has been thought and known in the world current everywhere; to make all men live in an atmosphere of sweetness and light, where they may use ideas, as it uses them itself, freely,- - nourished, and not bound by them" (1869: 49). Besides, Arnold insists that

The men of culture are the true apostles of equality. The great men of culture are those who have had a passion for diffusing, for making prevail, for carrying from one end of society to the other, the best knowledge, the best ideas of their time; who have laboured to divest knowledge of all that was harsh, uncouth, difficult, abstract, professional, exclusive; to humanise it, to make it efficient outside the clique of the cultivated and learned, yet still remaining the best knowledge and thought of the time, and a true source, therefore, of sweetness and light. (49) 
Because we address the interrelatedness of the humanities and education, this notion of culture is best considered in juxtaposition with the democratic spirit sparked by the French Revolution. The Revolution propelled a paradigmatic change in Western thinking about education and learning, as well as in the organization of and common access to schooling. This change took a long time to happen, and the spirit of civic equality made an uneven progress across and within societies, with its impact on individuals depending on their social class and background, gender, denomination, age, ethnicity, and minority status. This is why, in terms of current educational practices in Western societies, this vision, though systematically implemented and modified in social life, still has not made good on some of its promises.

Arnold's concept envisages education neither as the compiling of facts nor as the acquisition of skills, but as the formation of personalities, attitudes, and beliefs which promote cultural participation and the accomplishment of cultural ideals. Such inner molding is a prerequisite for building a democratic society, because such a society is founded on the endorsement of equality and on the engagement of citizens who are capable of both governing and being governed. The dissemination of knowledge and skills fostering appropriate personalities, attitudes, and beliefs lays the foundation for the development of an egalitarian society, and prepares people for involvement in its everyday operations. The humanities were expected to provide examples of key virtues of such personalities and mindsets. This kind of education was supposed to counteract the chaos of contemporary life by evoking the ancient unity of experience. Thereby, education itself was envisaged as a continuation of the pedagogies of Isocrates and Quintilian (though similar concepts and educational practices had been independently developed in other regions of the world as well). The unity of experience was founded on the concept of an integrated and self-controlled subject (Connell 1950). Without a doubt, such a notion of education emerged as a response to the turmoil of modernity. If modernity is, indeed, "the epoch in which the destruction of the world followed the collective attempt to master it," as William Connolly put it (1993: 1), the humanities as the foundation of education may offer a toolbox for understanding social and cultural transformations. The individual "self" is elevated above the confusion of modernity manifest in everyday life.

Another significant concept of culture is based on the notion of identity, in particular of national identity, and, in some measure, arose in opposition to the former, even though both insist that culture is the basic point of reference for education. Here, however, the focus is on shaping the national identity, rather than on perfecting the mind. Culture and cultural education have been invaluable for the countries in search of their identity or those which, like Poland, have endeavored to retain their national identity against external oppression. This concept of culture was fashioned by, for example, Johann Georg Hamman, Johann Gottfried von Herder, and, to a degree, Edmund Burke across the English Channel, as the Romanticism was chasing the Enlightenment away. These thinkers eulogized national culture as the most important component of individual identities. Accordingly, the vocation of the humanities was defined as chiseling national values, and education was tasked with imparting these values to students. Besides, both the humanities and education were assumed to be crucial for discerning the quintessentially national substance in various spheres of social life, environment, and heritage. This repositioning powerfully impacted the evolution of the humanities and education in respective countries, and fueled interest in history and in the affiliation of important artists, authors, and artefacts with particular nations and their lega- 
cies. This model assigned national languages a special role of expressing cultural meanings. Proposed by Hamann and Herder, and later honed by Wilhelm von Humboldt, this concept of language is, in our times, encapsulated by Charles Taylor as "the locus of different kind of disclosure. It makes us aware of the expressive dimension and its importance. And it allows us to identify a constitutive dimension, in which language does not only represent, but enters into some of the realities it is 'about'" (1985: 273).

All this means that one cannot become a conscious member of a community without knowing its tradition, art, and language. A considerable part of the 19th century in Europe was marked by concerted efforts to produce, develop, integrate, and protect national values. The humanities made a significant contribution to this enterprise by offering people elucidations of these values in multiple fields of knowledge (Gellner 2009).

The humanities have thus played a rather ambiguous role. On the one hand, they helped members of oppressed and neglected national groups regain the sense of national identity. On the other, however, they could and often did nurture narrow-minded, parochial sentiments. In his monumental study of anti-Enlightenment tendencies, Zeev Sternhell demonstrates that this concept of culture engendered a species of modernity that veers from the Enlightenment-defined model of the modern:

In Herder and among the Herderians, not only in Germany but also in France and Italy, there emerged cultural nationalism and its product, political nationalism, which, as one advanced into the twentieth century, became more and more radical and more and more and more violent. Cultural nationalism very soon gave birth to the idea of the nation state and its counterpart, the supremacy of the state and the idea that democracy is the enemy of the people. (2010: 101)

Clearly, the humanities may work both as a vehicle of a nation's deeper self-understanding and as a means of spreading the idea of a nation's superiority. In his book, Sternhell reveals how intimately the anti-Enlightenment modernity was implicated, if not complicit, in the rise of Fascism. Even if his argument is somewhat exaggerated, nationalist education seems likely to always harbor a serious risk.

The third important concept of culture is bound up with religion and faith, and consequently with a very particular vision of the destiny of man and the world which a given community upholds and which obligates this community to act in certain ways. Crucially, if the relations of respective religions to education are lucid and unambiguous, their attitude to the humanities is rather ambivalent. Across epochs, regions of Europe, communities, and creeds, (some of ) the humanities have been considered threatening or, on the contrary, attractive in one way or another. The history of attempts to harness the humanities to a given religious agenda is as long as the history of efforts to repudiate or combat them. In this context, Thomas Stearns Eliot's essay "Notes towards the Definition of Culture" (1948) provides some illuminating insights. Eliot deems religions to be a decisive factor in the cohesion and dynamic of culture. In his view, while in their embryonic stages religion and culture overlap, they part ways in modern societies, and even become antagonistic. Eliot regards the latter process as a symptom of cultural disintegration, and observes that "[r]eligious thought and practice, philosophy and art, all tend to become isolated areas cultivated by groups in no communication with each other" (1976: 98). This does not mean that Eliot believes that religion does not extend over national boundaries and region-specific cultures. Still, he is less concerned with theoretical precision and more with the future and local vari- 
ants of Christian culture, to which he ascribes an exceptional significance. Eliot's reasoning seems to be driven by the perils he perceives to the condition of the Christian religion, which prompt the decline of culture. To avert this, he recommends avoiding the extremes, because " $t$ the danger of freedom is deliquescence; the danger of strict order is petrifaction" (156). If the coherence and vitality of Western culture are to be sustained, it must cherish its robust connection to its religious foundation. This productive coupling is well conveyed in a passage on the functionality of distinctions among denominations or regions within the unity of Christianity:

Christendom should be one: the form of organisation and the locus of powers in that unity are questions upon which we cannot pronounce. But within that unity there should be an endless conflict between ideas - for it is only by the struggle against constantly appearing false ideas that the truth is enlarged and clarified, and in the conflict with heresy that orthodoxy is developed to meet the needs of the times; an endless effort also on the part of each region to shape its Christianity to suit itself, an effort which should neither be wholly suppressed nor left wholly unchecked. (157)

Since the integrity and the durability of Christianity are not effectuated or channeled by self-centeredness, not only its internal diversification but also the humanities are instrumental in its indispensable adaptation to the changing circumstances. This implies that the humanities are attractive for two reasons. Firstly, they reassert the religious foundation both by contemplating it in their explorations and self-reflection as well as by making it visible in art, which, according to Eliot, must deliberately or inadvertently build on this foundation. Secondly, a conflict with the humanities is capable of purifying and buttressing Christianity, which at the same time enhances the quality of culture. In other words, the humanities are positioned as a challenge in this framework. Another risk spotted by Eliot is associated with a considerable change in the relation of religion and education in modern Western societies. Specifically, Eliot insists that

$[t]$ here is also the danger that education - which indeed comes under the influence of politics-will take upon itself the reformation and direction of culture, instead of keeping to its place as one of the activities through which a culture realizes itself. Culture cannot altogether be brought to consciousness; and the culture of which we are wholly conscious is never the whole of culture: the effective culture is that which is directing the activities of those who are manipulating that which they call culture. (1976: 184)

Of course, Eliot's assertions invite questions and stir doubts. However, does not make them any less useful as an avenue for investigating the notions of culture which treasure religion (Astvatsaturov 2019). Yet Eliot's approach is hardly representative, and his views form a polar opposition to religious fundamentalists' attitude to education, Western culture, and the humanities. Rather than suggesting that any of these standpoints can or does ignore the status and the role that culture and the humanities boast in contemporary Western societies, this just means that they are differently positioned vis-à-vis these issues.

The three concepts of culture outlined above - one originating in the Enlightenment and the other two, mutually incommensurate ones, ensuing from anti-Enlightenment trends - are admittedly divergent. Nevertheless, they all share the idea that culture and the humanities as a vehicle of culture stand as the ultimate framework of reference for all manifestations 
of social life. This paramount status of culture was undermined in the latter part of the 20th century by a confluence of factors and circumstances which has come to be called a "crisis of culture." There is no common consensus as to what this phrase exactly means and what particular factors have contributed to this new state of affairs. The heterogeneous ensemble of developments cited as its symptoms comprises mass and popular culture, the mobilization of culture for political purposes, the compartmentalization of culture, the dominance of technology over culture, and multiculturalism. Varied though they are, what all these symptoms have in common is the dethroning of culture, which is no longer an end in and of itself, but merely a means. From this perspective, the humanities, which are pivotal to the self-reflection of culture, must redefine their role. Without relinquishing their function of a repository of cultural values, the humanities must adapt to the altered social conditions. They are still important as a source of society's self-reflection, but they can no longer aspire to the status of the univocal and ultimate expression of supreme reason.

\section{Everyday Life as a Measure of Culture, the Humanities, and Education}

To restate, the concepts rehearsed above all agree that culture and the humanities as a vehicle of culture provide the ultimate framework of reference for all manifestations of social life, including education. This means that even if the totality of educational practice in a given Western society could be regarded as varied in terms of its enculturation modes, the influences of basic socializing institutions (the education system, public media, religious organizations, cultural facilities, governmental agencies, etc.) have become relatively uniformized, regularized, and normalized over the last two centuries. The dynamics of modernity have produced a seminal change, demoting culture from its supreme position, and, concomitantly, discovering the meaning and the relevance of everyday life. Culture at this point is meant in its narrow meaning, which enables the humanities to define priority cultural elements and areas and then to conceptualize and apply them within the education system. Recognized as the principal symptom of the "crisis of culture," this change was already observable and assessed in the second half of the 20th century. As a result, a certain reversal has taken place, as everyday life, or, precisely speaking, social representations of everyday life are becoming the chief criterion for appraising culture, the humanities, and education.

This fundamental significance of everyday life is generated by a range of tendencies that shape modernity. As already stated, everyday life is the discovery of modernity. Of course, people have always inhabited everydayness, and contemporary historians laboriously study human daily activities in various ages as a part of culture in its broad meaning, a part which tended to be excluded from the images of culture dominant before modernity. Nevertheless, the modern age has made everydayness a touchstone of theoretical concepts, including pedagogical frameworks, as well as of educational practice. The three models of interrelations among culture, the humanities, and education evoked above seek to make young people capable of managing everydayness. This may involve both certain ways of getting by in everyday life (e.g., eschewing rash judgments) and certain ways of perceiving everyday life (e.g., looking at it from the distanced standpoint of high, national, or religious culture). One way or another, the three concepts share the idea that education secures individuals an implicitly privileged position in the society of everyday life. 
The very notion of everydayness begs a short explanation. Though ostensibly and popularly considered obvious, everydayness has sparked a plethora of interpretations and models in long-established sociological and historical research on everyday life, from pragmatism, the Chicago School, Lefebvre, and Schütz, to the Annales, Foucault, Bourdieu, and de Certeau, to the New Humanities. Norbert Elias explains that social research conceives everydayness in a variety of manners, for example, as the antinomy of festival, a lifestyle in mass society, a work day, routine, private life, a site of spontaneous experiences and actions, and the domain of naive, popular thinking, meaning-making, and related behavior (1998: 166174). Whatever framework they choose, researchers find it challenging to define everydayness with any tolerable accuracy, and, consequently, its various dimensions continue to be debated. Incomplete or imprecise though they may be, a panoply of accounts offers instructive scrutinies of everydayness. For example, Henri Lefebvre describes the everyday as

What is humble and solid, what is taken for granted and that of which all the parts follow each other in such a regular, unvarying succession that those concerned have no call to question their sequence; thus it is undated and (apparently) insignificant; though it occupies and preoccupies it is practically untellable, and it is the ethics underlying routine and the aesthetics of familiar settings. (1971:24)

To emphatically reiterate, it is modernity that discovers everyday life (however it is understood) and gradually discovers and recognizes its normativity. In other words, everyday life ceases to be - in particular, for the expanding middle class - a domain of the onerous, the routine, the schematic, the tedious, and the sacrifice-demanding. It morphs into something that is attractive, accessible, diversified, and capable of giving satisfaction and pleasure, while at the same time ordered and enclosed in stable cyclical rhythms. Existentially and cognitively familiar to the individual, everyday life focuses on handling the challenges, the basic human biological and economic needs, and consumption, is egalitarian to some degree, permits the exercise of subjective liberties, brings innovation and fads, abounds with things and utility objects, teems with events and sensations, holds sway over social engagements, and is reflected in the responsibilities of social institutions and in political agendas. As a result, everyday life comes to be the essential framework of reference in assessing developments in culture, the humanities, and education. This can be seen across the levels and spheres of social life.

Apparently, it is taken for granted today that social utility is the ultimate criterion for evaluating research results in the solid and natural sciences, and that the scale of everyday life problems determines the hierarchy of scientific findings, discoveries, and technologies. This affects the allocation of funding for research, social recognition and, in a measure, prestige in specialist communities. At least since the industrial revolution, the humanities and, subsequently, the social sciences have been entangled in confrontations with science models prevalent in the solid and natural sciences; these clashes have not left the responsibilities, goals, and values of the humanities and the social sciences intact. If the utility of the social sciences is now measured by how social research assists social policy-making, agendas of social institutions, the formation of society, and social engineering, the humanities with their aversion to a priori limits and subordination are still rather ambivalent about this yardstick. This ambivalent attitude is well reflected in disputes around formal education. Discussions on curriculum concepts indicate that advocates of the humanities believe that the humanities should have an influence on the moral, cognitive, and aesthetic standards 
of everyday life, even though at the same time they reject the idea of the humanities being judged by the tribunal of effectiveness and direct utility (Nussbaum 2016; Scott 2008). Instead, they would prefer the tribunal of, for example, enlightenment, patriotism, or creed, depending on what educational ideology they embrace.

However, regardless of the transformations of the university and the models of science, everyday life in modernity has been incrementally becoming pre-eminent in the pursuits of mainstream artists and authors in Western culture. The arts, philosophy, and scholarship have step by step privileged everydayness and matters of common people as their thematic concerns and raison d'être. Authors, writers, film- and stage directors, architects, scholars, and thinkers have invested more and more effort and skill in exploring the human and nonhuman quotidian experience and in sensitizing their audiences to the lives of lower social strata, to fashion systems, to interactive rituals and, more recently, to reality-show protagonists, to the work of bloggers and hobbyists, as well as to animals, plants, utility objects, waste, IT systems, artificial intelligence, and the monochromatic urbans spaces. Their dedication to probing these topics has been equal to that once showered on the predicament of king Lear, the Hebrew Bible research, and Plato's writings. Contemporary media, in combination with interactivity and popular culture, only bolster this message. While Duchamp's famous urinal or Bloom's meanderings in Dublin on 16th June 1903 could (and did) once raise eyebrows as acts of artistic extravagance, today most objects of everyday use and habitual rituals have had their histories well chronicled and stored in publicly accessible archives. They are all interesting. In the same way, Boule de Suif does not stand at all against the backdrop of Maupassant's other portrayals of orange sellers, washerwomen, infatuated waitresses, mothers desperately looking for jobs, and maidservants. Everyday life has become common in late modernity, but it has lost nothing of its attractiveness and charm. Rather, it has matured.

Equally saliently, everyday life is considered in Western societies the domain of the people rather than of the elites, with the people, as Margaret Canovan observes, espousing the belief that its consent is the only foundation of legitimate governance and that it has the right of self-determination (2005: 1). In other words, the preponderance of the sovereignty of the people and the value of common citizens and their everyday life reinforce each other. This has implications for contemporary liberal democracies, which must politically fend off not only the peril of tyranny, but also the danger of populism. If the governing elites do not use populist strategies, they are challenged to effectively and credibly rebut the double accusation of betraying the people: by robbing the people of power and by ignoring the problems of common citizens and their everydayness (Canovan 1981: 294-296; Mude, Kaltwasser 2017: 1-20). The risks of tyranny and populism that beset liberal democracy shed some light on the complexity of everyday life and its grim facets, such as humiliation, discrimination, abuse, anomie, alienation, crime, allergy to otherness, widespread focus on private life, lack of interest in public matters, predilection for entertainment and consumption, passive acquiescence, susceptibility to seduction and manipulation, etc. As everyday life needs understanding, support, and affirmation, which the humanities and education can provide, its bleak facets and related hazards to the democratic order call for activating the potential of criticism. Briefly, understanding, support, affirmation, and criticism of everyday life are responsibilities which afford the humanities an opportunity to retain their elevated status in the culture of anxiety. The question is what political and educational forms are best suited to bolster such interplays. In our view, the optimal forms of organization and 
action in the system of relationships outlined above are to be found in the concepts of nonconsensual democracy, critical community, and the pedagogy of asylum, with other options by no means excluded from the picture. These solutions are explained and substantiated in the following section.

\section{Critical Community, Non-consensual Democracy, and the Pedagogy of Asylum: Education and Everyday Life}

The transformations of modernity have increased not only the relevance of everyday life (which is reflected in the change of its status) but also its complexity, with everyday life becoming opaque, risky, and complicated. Everyday life is, as it were, attractive, accessible, variable, and diversified, and occasions satisfaction and pleasure; at the same time, it remains ordered and subject to stable cyclical rhythms, though it simultaneously breeds new, unavoidable challenges. Symptomatically, assistance from specialized experts is becoming necessary in selecting, using, and repairing appliances at homes, workplaces, and institutions, in career planning, child-raising, education, morality, personal and work relationships, information retrieval and management, identity formation, security, mental wellbeing, shopping, diet, sport, holiday-making, fashion, dating, cleaning, etc. The multiplicity of such experts and their diversified offer turn the freedom of choice into a stressful quagmire. The ensemble of more global developments - including the climate crisis, the pandemic, inequality, tension-ridden international and domestic politics, pollution, unemployment, corruption, exploitation, stock exchange fluctuations, corporate hegemony, crime, pathologies of bureaucracy, new technologies, the menaces of everydayness, etc.comprehensively affects everyday lives of common citizens of Western countries by adding new risks to the already familiar ones. Ensnared in the intricate web of these interrelated and interdependent processes, they lose the sense of control and agency, developing distrust and anxiety. Education and the humanities are crucially implicated in understanding the logic and complexity of everyday life, in supporting it through initiatives, solutions, and preparation for participation, in affirming its importance, advantages, and values through nurturing proper attitudes, and in offering its critique by illuminating its dynamic, tendencies, abuses, and hazards. The point is that everyday life does not possess enough self-awareness to respond to its dynamic. This self-awareness may only be brought into everyday life by the humanities. Education is among the most important means to this end. The university and higher education appear to be tolerably well equipped to face up to such responsibilities and perform them in the future alongside their other tasks. However, academy is internally diversified and cultivates cherished values of its own, such as research autonomy. Universities are still elitist institutions where a selected minority of the population is educated. At the same time, the changing dynamic of everyday life would call for a considerable flexibility from the academic community. These factors stir doubts as to whether the university is indeed ready and able to effectively handle the tasks listed above. Hence, we believe that other solutions should be given a serious thought. One that we consider particularly germane is discussed below.

Having established that the complexity of everyday life in democratic societies calls for the work of understanding, support, affirmation, and criticism, which may help the humanities retain their supreme status, we can ponder what forms best suit this assemblage of rela- 
tionships. In our view, non-consensual democracy, critical community, and the pedagogy of asylum are the optimal models of organization and action in the system interrelations depicted above. These notions are associated with familiar forms which are widely exercised in democratic societies, and as such they do not require augmenting social practice with novelties which would be confrontational vis-à-vis everyday life and thus come across as strange and artificial. Rather, these notions are helpful because they accommodate existing practices, generate new understandings of them, and adjust them to the current sociohistorical conjuncture.

In his Politics of Dialogue: Non-Consensual Democracy and Critical Community, Leszek Koczanowicz (2015) put forward a concept of democracy anchored in American pragmatism and pivoting on the concept of dialogue, as developed by the Russian thinker Mikhail Bakhtin. Koczanowicz's framework is informed by the idea that dialogue is a vehicle of understanding rather than of agreement. This approach to dialogue underlies the notion of critical community, that is, a community which is involved in an ongoing dialogue with its own communal tradition. Critical community is a "third way" that negotiates between the liberal society of autonomous individuals and a strong community of values promoted by the communitarians. As such, critical community is a community of understanding and of dialogue with the cultural legacy. The individual is steeped in a certain tradition, which limits his/her autonomy, but $\mathrm{s} / \mathrm{he}$ is capable of taking a critical position on this heritage. At the same time, a critique does not preclude understanding. In more vivid terms, we seek to understand the choices and decisions made by our ancestors, even if we do not fully agree with them and even if we radically oppose them. Thus, dialogue with tradition is not about a simple rejection or acceptance of this tradition, but rather about a critical assimilation of it. Critical community finds its political form in non-consensual democracy, that is, a democracy in which institutions seek to promote mutual understanding among various political movements and social groups. Critical community and non-consensual democracy come with a number of implications, one of them being the continuity of everyday life and politics.

Dialogue - non-consensual dialogue - is ubiquitous; it appears in all societies, even the most oppressive ones, and social life would be impossible without it. Actually, the more oppressive a society is institutionally and politically, the more robust the live texture of dialogue in everyday life becomes. This results from the fact that relations in everyday life serve as a compensation for constraints in the public sphere, and the private sphere comes to fulfil the function of the absent public sphere (Koczanowicz 2008). Still, the basic issue is how to transplant dialogue which thrives in everyday life into the realm of politics. The question is why everyday life and politics are conterminous in some societies, while in other ones the two spheres are separated by an insurmountable barrier. This question is currently becoming pertinent, as liberal democracy with its elaborate patterns that promote dialogue across the areas of social and political activity is crumbling worldwide (Mounk 2018). One explanation of this process has been proposed by the political scientist and psychologist Shawn Rosenberg (2019), who argues that the degree of procedural complexity in democratic societies prevents most people from political participation. As opposed to this, populism draws easily comprehensible divisions and envisions graspable solutions to social problems, as a result of which its popularity is soaring. Rosenberg insists that education that prepares people for navigating institutional intricacies is the only viable response to this challenge. 
Without a doubt, education is crucial in this respect, but its goals and values should be articulated in terms of critical community and non-consensual democracy. If democracy is primarily an exercise in mutual understanding, and participation in community hinges on the critical scrutiny of its traditions, education must be channeled in very particular ways. Generally, it should teach tolerance of disagreement and conflict, while at the same time shaping the capacity to understand other people's motives and attitudes. These skills are essential for democratic society in terms of its political operations. Besides, education should prepare people for engaging in dialogue with the cultural legacy of their own community. The two aspects are inextricable, because the strength of non-consensual democracy always ensues from its critical stance vis-à-vis tradition.

To attain such goals and to make educational and political practice formative of critical community effective requires measures compatible with the ideas of non-consensual democracy. The construction of critical community and non-consensual democracy must commence somewhere, and neither education designed to nurture them nor education designed to promote their continuity and permanence must be at variance with them. The chief question would be how to implement educational and political practice as depicted above, and yet realize that such efforts must neither count on a broad educational consensus nor be based on imposed solutions. Moreover, the concepts of non-consensual democracy (a democracy to come) and critical community as solutions that respond to the weaknesses, shortcomings, defects, and crises of the existing organizational forms of society and everyday life do not entail abandoning educational pluralism; they only call for buttressing the tendency that is instrumental in making non-consensual democracy and critical community a reality. Hence the recourse to the pedagogy of asylum.

Developed by Rafal Włodarczyk (2009), the pedagogy of asylum is informed by his interpretation of Levinas's philosophy, and develops Levinas's concept of subjectivity as hospitality that welcomes another human being (Levinas 1969: 27), his insistence on responsibility for the Other, and his idea of ethics as first philosophy (Levinas 1998a: 1-11; Levinas 1991: 157-161). Because Levinas's thought has attracted a considerable interest from educational theory and philosophy for at least two decades now (see Egéa-Kuehne 2008; Zhao 2018), his notion of responsibility for and to the Other is undoubtedly well known (see Todd 2003; Strhan 2012; Biesta 2013; Joldersma 2014). Levinas's radically conceived responsibility of the Self for and to the Other and ethical sensitivity as the foundation of subjectivity, which receives the call of the Other from the outside, pose an educational challenge. It is so because the culture of immanence, as Levinas depicts Western culture (1969: 35-40; Cohen 2004: 145-160; Alexander 2014: 58-68), has generated socialization and upbringing practices which make the Self insensitive and furnish it with rationalizations, leaving it apathetic vis-à-vis the alterity of the Other. Consequently, the Other is not sheltered against violence that originates in the Self. Nevertheless, Levinas (1991: 29-129) claims that whenever the Self engages in a relationship with the Other, the Self inadvertently risks becoming unsealed. The pedagogy of asylum highlights the importance of the sites and other factors that contribute to making this unsealing a safe process and promote the educational potential of the Self-Other encounter.

Explicitly inspired by the Judaic thought and legacy, Levinas's investigations of the foundations of morality and ethics, as well as his concept of subjectivity as hospitality that welcomes another human being, are expressed in the language of phenomenology, one of the recognized idioms of the Western philosophical tradition, which grievously failed to 
develop a credible and convincing alternative to the allergy to otherness, an evil that Levinas identified in Nazism (Levinas 1998b: 91-101; Cohen 2004: 266-282) before the dark decade of the 1930s. That symptoms of this allergy have been resurfacing in everyday life after WW2 is a warning that a relapse is indeed possible in culture and society. Levinas's critical investment is induced by the observation that living up to the ethics of hospitality is a challenge to everyday life, permeated, as it is, by social and legal norms, cultural patterns, and customs which contravene what Levinas defines as responsibility toward the Other. Given this, education for hospitality requires an asylum, because the essential socializing institutions, such as family, school, media, religious organizations, associations, peer and social groups, workplaces, and government agencies, fail to foster the habits of $\mathrm{f}$ decisionmaking founded on the ethical core of subjective sensitivity captured by Levinas. Moreover, social expectations, which make up morality, law, and custom, permeate everyday life and are communicated to the subject as the equivalent of his/her responsibility. In this context, tapping into the potential of education is spurred not only by a deficit of dedicated sites in the social space where subjects could scrutinize their core of ethical sensitivity, but also by the fact that this deficit cannot be remedied without a concerted effort for developmental change. In this sense, the asylum is supposed to provide a contrast with the realities of everyday life.

Adopting such tenets, Włodarczyk discerns a potential of developmental change consistent with the ideas of the pedagogy of asylum not so much in purpose-designed educational settings as rather in transformations and oscillations of the already existing groups, associations, and institutions - Enlightenment-affiliated, religious, and national ones alike. The point is that habits and experiences congruent with the ethics of hospitality are premised not on their interests or goals, but, instead, on the nature and quality of relations they establish. The habits and experiences formed in such asylums may later serve individuals as points of reference in other social spaces and in their everyday life, in this way bolstering one of educational tendencies. The pedagogy of asylum produces proper conditions for people to learn to tolerate disagreement and conflict, and nurtures commitment to understanding other people's motives and attitudes, as well as to engaging in dialogue with the cultural legacy of one's own community. This mindset and attitudes are indispensable for critical community and non-consensual democracy and are achievable through a gradual expansion of the ethics of hospitality beyond asylums. Critical community and non-consensual democracy arise from educational practices of individual asylums, which will be preparing people for non-consensual dialogue as small, diversified groups and which will be able to sustain such a mutual dialogue with other, different groups. The pedagogy of asylum is thus an approach that includes an educational alternative which can weave its way into Enlightenmentinspired, religious, and national settings as a counterbalance to their inhospitality-promoting and violence-instilling practices. Since critical community and non-consensual democracy must begin somewhere, they may — similarly to many other social utopianisms - take their beginning in asylums.

This is how the notions of critical community, non-consensual democracy, and the pedagogy of asylum answer to the still relevant demand of the education - or pedagogy of hope, which is championed in and beyond the American variety of critical pedagogy (Webb 2013a: 397-414; Webb 2013b: 280-290; Freire, Freire 1994: 7-10; Giroux 2006: 45-63; Gur-Ze'ev 2001: 315-336; hooks 2003: xiv-xvi; Halpin 2003: 10-44). Yet, the three notions have an even closer affinity with the ideas and positions of critical pedagogy, a 
comprehensive movement which has been evolving since the early 1980s (Kincheloe et al. 2017: 418-465), if not since the 1960s, if its earlier, German species is taken into account (Warddeker, Miedema 1997: 45-47). At the same time, critical community, non-consensual democracy, and the pedagogy of asylum are explicitly indebted to the philosophy of dialogue, and are more profoundly inspired by the dialogic thought than critical education theories are (Matusov, Miyazaki 2014: 2-16; Burbles 2017: 553-557). As such, they represent a merger of critical and dialogic traditions. Both these traditions appreciate everyday life and the humanities, the spheres which are particularly in need of mediation and support from education in the age of the crisis of culture.

\section{Conclusions}

In seeking to establish what role the humanities can play in a culture haunted by the crisis of higher education, we discussed how the role of the humanities changed in parallel to the changing definitions of culture, and outlined three pre-eminent current understandings of culture. Subsequently, we focused on how culture, in its narrow meaning, lost its dominant status in the wake of the discovery of everyday life in modernity. As everyday life gradually came to preoccupy the artists and authors who defined the prevalent tendencies of Western culture in modernity, a reversal took place in which everyday life or, more precisely, social representations of everyday life and its practices became the central criterion for appraising culture, the humanities, and education. At the same time, everyday life as such has lost none of its complexity and ambiguity either in theoretical conceptualizations or in research observations. For example, everyday life is replete with risks and anxieties which are only veiled by its obviousness and reinforced by socialization. This insight prompts the conclusion that everyday life requires the work of understanding, support, affirmation, and criticism, in which the humanities can retain their superior status, and that, simultaneously, everyday life calls for forms of organization and action aligned with this system of relations. Non-consensual democracy, critical community, and the pedagogy of asylum count among such relevant forms. Our approach clearly differs from the educational concepts which envisage education instrumentally as a method for producing "human capital." Sensitivity to the Other and understanding are irreconcilable with the vision of education as offering vocational training or developing manipulation-based human management skills, no matter how subtle and ostensibly ingenious such manipulation might be. Our proposal also differs from the concepts that champion a return to values as the basis of education or, at least, plead for complementing the instrumental approach to education. Respectable though such pursuits may be, they evoke the three old models of education and are detached from the world of everyday life. In political and citizenship-education terms, these concepts are founded on consensual dialogue and endorse agreement as the ultimate goal of social life. In our approach, the role of the humanities in culture hinges on their capacity to problematize everyday life and disseminate practices that promote such a problematization, because, in modernity, everyday life has become the central point of reference in Western democracies, while, in and of itself, it has no proper self-reflective capacity. The spotlight on everyday life as a site where the most important social issues are decided is where we differ from the traditional views on the humanities. While the salience of social life has been recognized in some scholarly theories, this appreciation has not yielded any meaningful implications 
for education. Hence, in our view, the schooling system, including university education, is currently incapable of fostering a reflective approach to everyday life in all its extraordinary complexity. The formal frameworks of education, including tertiary education, thwart the work of understanding, support, affirmation, and criticism of everyday life. As they deviate from everyday life existentially, programmatically, administratively, organizationally and in other ways (Włodarczyk 2019: 105-120), the experiences they engender rarely correspond to those offered by other learning settings (Illeris 2002). Our proposal helps activate the potential of everydayness. However, new intellectual tools are needed to tap into this potential. Asylum, non-consensual dialogue and critical community add up to a useful toolkit which may be instrumental in forging a new perspective on education. This approach may halt the progressing marginalization of the humanities, which still found their raison d'être on the expectations related to the effectiveness of social institutions. However, the problematization of everyday life cannot be imposed top-down as a curricular item or a learning outcome of higher education. The practice of understanding, support, affirmation, and criticism of everyday life requires proper conditions, training, and experience, which cannot be provided by university today, because, for one, university has itself been converted into a social institution, one among many. Besides, for higher education to perform this obligation would take a broad consensus underpinned by the acknowledgement both of the late-modern challenges and of the relevance and superiority of the humanities. While the achievement of such a consensus is not very likely, the unsolved contradictions of everyday life call for an education-mediated humanistic intervention. We believe that fitting responses to this challenge are offered by the concepts of non-consensual democracy, critical community, and the pedagogy of asylum, which in the long run may alter the perception of the humanities in culture and contribute to the overcoming of the crisis of higher education.

Open Access This article is licensed under a Creative Commons Attribution 4.0 International License, which permits use, sharing, adaptation, distribution and reproduction in any medium or format, as long as you give appropriate credit to the original author(s) and the source, provide a link to the Creative Commons licence, and indicate if changes were made. The images or other third party material in this article are included in the article's Creative Commons licence, unless indicated otherwise in a credit line to the material. If material is not included in the article's Creative Commons licence and your intended use is not permitted by statutory regulation or exceeds the permitted use, you will need to obtain permission directly from the copyright holder. To view a copy of this licence, visit http://creativecommons.org/licenses/by/4.0/.

\section{References}

Alexander, Hanan. 2014. Education in Nonviolence: Levinas' Talmudic Readings and the Study of Sacred Texts. Ethics and Education 1: 58-68.

Astvatsaturov, Andrey. 2019. On the way towards canon-formation: the case of T. S. Eliot. World Literature Studies 11(1): 42-50.

Arnold, Mathew. 1869. Culture and Anarchy. London: Smith, Elder and Co.

Biesta, Gert J. J. 2013. The Beautiful Risk of Education. London, New York: Routledge.

Burbles, Nicolas C. 2017. Dialogue and critical pedagogy. In Encyclopedia of Educational Philosophy and Theory, ed. Michael A. Peters, 553-557. Singapore: Springer.

Canovan, Margaret. 1981. Populism. New York, London: Harcourt Brace Jovanovich.

Canovan, Margaret. 2005. The People. Cambridge: Polity Press.

Cicero, Marcus T. 2005. Tusculan Disputations. 14998. Project Gutenberg E-book.

Cohen, Richard A. 2004. Ethics, Exegesis and Philosophy. Interpretation after Levinas. Cambridge: Cambridge University Press. 
Confucius. 2003. Analects. With Selections from Traditional Commentaries. Indianapolis, Cambridge: Hackett Publishing Company.

Connell, William F. 1950. The Educational Thought and Influence of Matthew Arnold. London: Routledge.

Connolly, William E. 1993. Political Theory and Modernity. Ithaca: Cornell University Press.

Eagleton, Terry. 2000. The Idea of Culture. Oxford, Malden: Wiley- Blackwell.

Egéa-Kuehne, D., ed. 2008. Levinas and Education. At the Intersection of Faith and Reason. London, New York: Routledge.

Elias, Norbert. 1998. On the concept of everyday life. In The Norbert Elias Reader, eds. Johan Goudsblom, and Stephen Mennell, 166-174. Oxford: Blackwell.

Eliot, Thomas S. 1976. Christianity and Culture. The Idea of a Christian Society and Notes towards the Definition of Culture. San Diego, New York, London: A Harvest Book.

Freire, Paulo, and Freire, Ana Maria Araújo. 1994. Pedagogy of Hope: Reliving Pedagogy of the Oppressed. New York: Continuum.

Gellner, Ernst. 2009. Nation and Nationalism. Ithaca: Cornell University Press.

Giroux, Henry A. 2006. Dystopian nightmares and educated hopes: the return of the pedagogical and the promise of democracy. In Edutopias: New Utopian Thinking in Education, ed. Michael A. Peters, John Freeman-Moir, 45-63. Rotterdam: Sense Publishers.

Gur-Ze'ev, Ilan. 2001. Philosophy of peace education in a postmodern era. Educational Theory 3: 315-336.

Hadot, Pierre. 2001. The Inner Citadel. The Meditations of Marcus Aurelius. Cambridge, Mass: Harvard University Press.

Halpin, David. 2003. Hope and Education. The Role of the Utopian Imagination. London, New York: Routledge Falmer.

Hooks, Bell. 2003. Teaching Community. A Pedagogy of Hope. New York, London: Routledge.

Illeris, Knud. 2002. The Three Dimensions of Learning: Contemporary Learning Theory in the Tension Field between the Cognitive, the Emotional, and the Social. Copenhagen: Roskilde University Press.

Joldersma, Clarence W. 2014. A Levinasian Ethics for Education's Commonplaces. New York: Palgrave Macmillan.

Kincheloe, Joe L., Peter McLaren, R. Steinberg Shirley, and B. Manzó Lilla. 2017. Critical pedagogy and qualitative research: advancing the bricolage. In The Sage Handbook of Qualitative Research, ed. Norman K. Denzin, Yvonna S. Lincoln, 418-465. 5th Edition. Los Angeles, Melbourne: Sage Publications.

Koczanowicz, Leszek. 2008. Politics of Time: Dynamics of Identity in Post-Communist Poland. New York: Berghan Books.

Koczanowicz, Leszek. 2015. Politics of Dialogue: Non-Consensual Democracy and Critical Community. Edinburgh: Edinburgh University Press.

Lefebvre, Henri. 1971. Everyday Life in the Modern World. New York, London: Harper Torchbooks.

Levinas, Emmanuel. 1969. Totality and Infinity. An Essay on Exteriority. Pittsburgh: Duquesne University Press.

Levinas, Emmanuel. 1991. Otherwise than Being or Beyond Essence. Dordrecht: Springer Netherlands.

Levinas, Emmanuel., ed. 1998a. Is ontology fundamental? In Entre Nous. On Thinking-of-the-Other. New York: Columbia University Press.

Levinas, Emmanuel., ed. 1998b. Useless Suffering. In Entre Nous. On Thinking-of-the-Other. New York: Columbia University Press.

Matusov, Eugene, and Kiyotaka Miyazaki. 2014. Dialogue on dialogic pedagogy. Dialogic Pedagogy: An International Journal 2: 1-47.

Mounk, Yascha. 2018. The People vs. Democracy: Why Our Freedom Is in Danger and How to Save It. Cambridge, Mass: Harvard University Press.

Mudde, Cas, Kaltwasser, Cristóbal R. 2017. Populism. A Very Short Introduction. Oxford: Oxford University Press.

Nussbaum, Martha C. 2016. Not for Profit. Why Democracy Needs the Humanities. Princeton, Oxford: Princeton University Press.

Pascal, Nanette R. 1984. The Legacy of Roman Education. The Classical Journal 79: 4 351-355.

Rosenberg, Shawn. 2019. Democracy devouring itself: the rise of the incompetent citizen and the appeal of right wing populism. In Psychology of Political and Everyday Extremisms, ed. Domenico Uhng Hur, José Manuel Sabucedo. Brazil: Editora Vozes.

Scott, David. 2008. Critical Essays on Major Curriculum Theorists. New York, London: Routledge.

Sternhell, Zeev. 2010. The Anti-Enlightenment Tradition. Hew Haven: Yale University Press.

Strhan, Anna. 2012. Levinas, Subjectivity, Education. Towards an Ethics of Radical Responsibility. Oxford: Willey-Blackwell.

Taylor, Charles. 1985. Theories of meaning. In Charles Taylor, Human Agency and Language, 248-292. Cambridge, New York: Cambridge University Press. 
Todd, Sharon. 2003. Learning from the Other. Levinas, Psychoanalysis, and Ethical Possibilities in Education. New York: State University of New York Press.

Warddeker, Willem L., and Siebren Miedema. 1997. Critical pedagogy an evaluation and a direction for reformulation. Curriculum Inquiry 27: 45-61.

Webb, Darren. 2013a. Pedagogies of hope. Studies in Philosophy and Education 32: 397-414.

Webb, Darren. 2013b. Critical pedagogy, utopia and political (dis)engagement. Power and Education 5: 280-290.

Włodarczyk, Rafał. 2009. Lévinas. W stronę pedagogiki azylu. Warszawa: Wydawnictwa Uniwersytetu Warszawskiego.

Włodarczyk, Rafał. 2019. Schools “detached” from reality. On the architectonics and dynamics of contemporary educational space. In Utopia, Ideology and/or Everyday Education Practice, ed. Wiktor Żłobicki., Wrocław: Instytut Pedagogiki Uniwersytetu Wrocławskiego.

Zhao, Guoping., ed. 2018. Levinas and the Philosophy of Education. New York: Routledge.

Publisher's Note Springer Nature remains neutral with regard to jurisdictional claims in published maps and institutional affiliations. 